\title{
SUPPLY AND DEMAND CHAIN MANAGEMENT: THE EFFECT OF ADDING SERVICES TO PRODUCT OFFERINGS
}

\author{
Dr Oscar F. Bustinzał*, Dr Glenn Parry† and Dr Ferran Vendrell-Herreroft \\ f*Universidad de Granada
}

$\dagger$ Bristol Business School, University of the West of England

$1 \neq$ University of Birmingham

The researchers would like to acknowledge the support of Bristol Business School for providing support for the research. Oscar F. Bustinza acknowledges financial support from ECO2010-16814. Ferran VendrellHerrero acknowledges financial support from SEJ 2007-67895-C04.

\section{Bios}

Oscar F. Bustinza, Ph.D.(University of Granada) is an Associate Professor of strategy and operations management at the University of Granada, Spain. His work aims to capture successful business practices, analyzing drivers of firm's boundaries choice and the leveraging of supplier, customer or inter-firm relationships based upon data driven analysis. Dr. Bustinza's research has been published in the International Journal of Operations and Production Management, Industrial Management and Data Systems, International Journal of Production Economics, Journal of Supply Chain Management, International Journal of Production Research, and British Journal of Management among other outlets

Glenn C Parry, Ph.D.(Cantab) is an Associate Professor of Strategy and Operations Management at the University of the West of England, UK. His research is characterised by a strong industrial focus on process combined with the rigour of academic analysis. His work aims to capture leading practice, moving companies forward through transformations based upon data driven analysis. He has been published in a number of international journals and has published the books, "Build to Order: The Road to the 5-day Car", "Complex Engineering Service Systems" and "Service Design and Delivery" which was ranked in The IIJ top 20 upcoming design books for innovators. He is currently involved in Enterprise Transformation, studying the move of complex engineering companies from product to service provision

Ferran Vendrell-Herrero, Ph.D.(Universitat Autonoma de Barcelona) is a lecturer in managerial economics in Birmingham Business School, University of Birmingham, UK. He completed his doctorate in the autumn of 2008, working on the analysis of university spin-offs specificities. His current research interests include Strategic Management, Entrepreneurship, Innovation and the analysis of the Music Industry. Dr. Vendrell-Herrero's research has been published in the International Journal of Production Economics, Small Business Economics, Regional Studies, International Entrepreneurship and Management Journal and Venture Capital among other outlets 


\begin{abstract}
Purpose - The purpose of this study is to understand how firms manage their product and service offerings, integrating Supply Chain Management (SCM) and Demand Chain Management (DCM) strategies. Adding services to the product portfolio of a firm may bring benefits to an organisation, but requires a reconsideration of the supply chain management approach.

Design/methodology/approach - A survey is used to collect data, with valid questionnaires obtained for 4,227 UK based respondents. Empirical analysis utilises Structural Equation Modelling (SEM).

Findings - The paper proposes that a combination of management approaches is required by firms who add services to their portfolio of tradition product offerings. A supply chain management approach may be suitable for traditional product offerings. The management of the services value chain, where the customers' role as value creator is a central feature of the construct, is better served by integration of the market orientation of Demand Chain Management.

Originality/value - The paper addresses a research gap related to the shift in traditional activities carried out by a firm moving from purely product to a product service offer and reconsiders the supply and demand chain management approach. The paper is from a Business to Consumer (B2C) perspective. In this context, the work pioneers analysis into a particular case where a firms' product and service offerings may be substitutes for each other in the eyes of the customer.
\end{abstract}

Keywords: Supply and demand chain management, servitization, customer linking.

\title{
1. Introduction
}

Supply chain management (SCM) is conceptualized as the network of organizations, linked upstream and downstream in processes and activities, producing products and services which are delivered into the hands of the ultimate customer (Christopher, 2005). SCM competency is empirically linked to improved firm performance (Ellinger et al., 2011) and influences customer satisfaction (Green et al., 2006; Parry et al., 2010). Demand Chain Management (DCM) recognises customer demand and communicates that demand through to suppliers (Cambra-Fierro and Polo-Redondo, 2008), modelling the dynamics of the visibility of customer demand (Holmström et al., 2010). Demand oriented-firms recognise customers' needs by drawing upon information from market 
sensing, customer linking and channel bonding (Jaworski and Kohli, 1996; Wong et al., 2012).

Manufacturing firms have been changing their portfolio of offerings, increasingly providing service in addition to their traditional product offerings; a process named servitization (Vandermerwe and Rada, 1988). These services take numerous forms including: customer support (Goffin, 1999), Through Life Management (TLM) (Johnsen et al., 2009) and availability contracting (Ng et al., 2011). This paper addresses the research question 'How does changing the offering affect supply \& demand chain management?'

The value of any offering is realised in its use which does not necessarily require the transfer of asset ownership (Vargo and Lusch, 2008). Product and service offerings can be substitutes for each other. Demand for digital 'service' output has been displacing tradition physical goods in the creative industries (Edwards et al., 2011), a process likened to the servitization of manufacture (Parry et al., 2012). Digitization means supply chains have fundamentally changed (Graham and Smart, 2010) with costs of production and distribution significantly reduced (Byrne, 2012). However, customers are less willing to pay for digital content (Oberholzer-Gee and Strumpf, 2007) creating challenges for these industries related to the operation of firms in the market and consumers illegal file sharing activity (Bustinza et al., 2013). This paper focuses only upon the supply chain management challenge.

Maximization of value is achieved through appropriate integration of supply and demand chains into a value chain focused on final customer requirements (Singh and Power, 2009). Through a fine adjustment of the demand-supply chain suppliers can offer their customer's new value propositions (Holmström et al., 2000). Guidance on SCM has been predominantly developed from studies of manufacturing (Maull et al., 
2012). There is debate within academia about the transferability of theories from manufacturing to service contexts (Ellram et al., 2006; Sampson, 2010; Stock et al., 2010). Few studies have investigated how firms generate value when they add services to the traditional manufacturing offering (Ellram et al., 2007; Vandermerwe and Rada, 1988). The appropriateness of retaining the same SCM approaches when services are added requires further analysis (Bettis and Hitt, 2007). With these antecedents, the research examines the effect on a firms' value chain when external market pressures require the introduction of service offerings. This paper is of particular practical interest from a supplier perspective as it analyses how the same customer may be served in multiple ways and how this can best be organized. The case example in this paper is drawn from the music industry. The analysis of supply and demand chain management is novel because it considers products and services which may act as substitutes for each other.

This paper is organized into seven sections, with the following section examining literature on supply and demand chain theory. Service operations and the role of customers are presented, drawing upon existing frameworks. In the third section a conceptual model and research hypotheses are developed. Subsequently the empirical methodology used to test the conceptual model is given. Findings are then explained and the paper concludes with academic and managerial implications, limitations of the study and proposals for future work.

\section{Literature Review}

\subsection{Supply and demand chain management}

SCM is a system based approach viewing the supply chain as a whole, looking at inter and intra-firm operational and strategic capabilities synchronization, and focussed on 
creating customer value (Mentzer et al., 2011). This concept allows an analysis of all the existing flows in a supply chain, from raw material through to delivery of an output to the final customer (Collin et al., 2009). The differentiator between supply and demand chain management is SCM focuses upon the creation of offerings and their transfer, flowing from suppliers to consumers. In contrast DCM is based on identifying customer needs and the transfer of demand signals from the market (Cambra-Fierro and Polo-Redondo, 2008). SCM and DCM may be characterised as upstream and downstream oriented respectively.

In analyzing the supply chain network a firm's collaboration with both their suppliers and customers is an essential theme in SCM literature (Horvath, 2001). An integrative philosophy is required in the management of the total distribution channel of suppliers to the ultimate customer (Ellram and Cooper, 1990). Most firms limit the span of control to their intermediate customer and fail to analyze the complete distribution channel through to the final customer (Singh and Power, 2009). A SCM perspective provides competitive advantage through the configuration and management of supply chain processes and operations (Dyer and Nobeoka, 2000). In this context supplier linkages are the most important determinant of performance (Lee et al., 2007). When companies continue to enjoy benefits they come to believe that their management of the value chain is appropriate. However, whilst frequently treated as passive recipients, consumers are dynamic and firms need to continuously reassess their effectiveness in delivering to customer needs (Canever et al., 2008). SCM seeks the optimisation of manufacturing and logistics but is conceptually silent on customer needs; an element for which the whole supply chain is dependant.

Theoretically SCM may be seen as a precedent of DCM as the latter emphasizes the development of actionable strategies based upon customer information which are to 
be employed by partners in the integrated supply chain (Jüttner et al., 2007). DCM analyses the customer perceived benefits obtained from a product or a service and compares them to the purchasing price (Johnson et al., 2008). The objective of DCM is to align SCM processes such that they achieve greater customer responsiveness (Godsell et al., 2006). Analysis of consumer preferences is of great importance for services as the consumer has a central role as a resource in service production (Anderson et al., 1997; Parasuraman et al., 1985; Vargo and Lusch, 2008). Where there is a rapid uptake of technology and a shift in power away from suppliers towards the consumer DCM becomes critical (Soliman and Youssef, 2001). Demand chain design is based on a profound market understanding and has to be effectively managed to meet different customer's needs (Agrawal, 2012). Juttner et al. (2007) define DCM under the paradigm of new business models aimed at creating value by combining the strengths of marketing and supply chain competencies. Under this conceptualization, DCM is understood as a dynamic network that facilitates the firm's capability to establish, maintain and enhance profit-making relationships with customers (Chase et al., 2007). DCM is based upon a customer-focused business culture (Lin et al., 2012) and it is able to pool channel resources to create additional value (Agrawal, 2012).

The literature provides two arguments for DCM's adoption (Frohlich and Westbrook, 2002). First, to gain greater access to new markets DCM allows the firm to achieve real competitive advantage (Vollmann et al., 2000). Additional value is achieved as DCM satisfies existing customer requirements and those of the most profitable customers in the new markets. The second explanation for DCM's adoption is the anticipated internal performance improvement. DCM coordination reduces variability and eliminates non value adding activities, which has a bearing on operational performance (Metters, 1997). There are other external pressures which drive 
adoption of DCM principles, for example: the bandwagon effect from competitive organizations that have already adopted DCM (Tolbert and Zucker, 1983); and the bullwhip effect, which can be moderated through sharing point-of-sales data and

alignment of process with final customer demand (Lee et al., 1997). The depth of demand chain integration possible is dependent upon the visibility and insight a provider is able to obtain or access from the customer (Collin et al., 2009; Holmström et al., 2010).

\subsection{Service analysis in the SCM literature}

Services as outputs or offerings usually have higher margins than products (Anderson $e t$ al., 1997), they are more difficult to imitate and therefore are seen as a sustainable source of competitive advantage (Heskett et al., 1997).Wise and Baumgartner (1999) observed a movement by manufacturers 'downstream', seeking additional sustainable revenues from services which support or are related to the use of a product. The introduction of service outputs or offerings in traditional manufacturing firms constitutes a major managerial challenge as service requires different management principles, structures and processes than products (Oliva and Kallenberg, 2003; Wise and Baumgartner, 1999). This paper explores service offerings which are different to those discussed by Wise and Baumgartner (1999) as the focus here is upon business to retail consumer (B2C) offerings where the product and services are alternatives or substitutes in the eyes of the customer.

When product and services can be seen as substitutes, customer heterogeneity is restricted to how much they are willing to pay for a given level of quality (Desai, 2001). To be successful additional offerings have to provide an increase in quality with respect to the original product offer (Atasu and Souza, 2012). New additional service offerings 
increase value only when the customers' demand chain is examined and the value offerings correspond to the changing needs of individual customers (Småros et al., 2000). In service provision customers are dynamic, playing a key role in the process of value realisation, employing their own resource (Prahalad and Ramaswamy, 2000). Customer participation presents a potential source of uncertainty and gives the customer insight into provider processes (Giannakis, 2011) requiring use of appropriate coordination and isolation mechanisms (Larsson and Bowen, 1989). In this study it is argued that customer participation in service process makes it necessary to reconsider the management approach used, promoting greater focus on DCM (Grönroos, 1994; Grönroos, 2011). DCM approaches are responsive to shifting value offerings in supply operations (Hoover et al., 2001), and incorporate customer demand chains and service supply chains as primary constructs. At the point of interaction between demand and supply the visibility of a customer requirement acts as a signal for suppliers to allocate resources in response. Firms can examine the level of customer demand visibility (Collin et al., 2009), enabling them to reorganize customer and supplier operations based on levels of visibility and further act if the level of visibility required for an offer is found to be insufficient (Holmström et al., 2010).

\section{Conceptual Model and Research Hypotheses}

Firms offering service must manage customers through appropriate link channels and consider both temporal and spatial factors (Forrester, 1961). Bowersox and Closs (1996) define channels as the structure of inter-company units and extra-company agents and dealers, wholesale and retail, through which a commodity, product or service is marketed. This research is limited to the link channels which establish dependencies between companies and the final customers as the objective is to analyse the effect on 
the value chain of the introduction of services to retail customers. These link channels, as the primary customer engagement points, are determinants in the process of understanding customer needs and providing visibility of their demands. The research framework is developed such that variables are analyzed using a model representing the relationships established with customers through these link channels.

With regards to other variables included in the model, service operations systems are analyzed as a natural broadening of production management (Johnston, 1999) and joint offering of products and services have developed (Wilkinson et al., 2009) which draw upon numerous resources, including the customer (Prahalad and Ramaswamy, 2000). In this context, the creation of value must be understood through the eyes of the customer (McNaughton et al., 2002).

\subsection{Studies in the creative industries}

Studies of supply chain management practice spanning numerous industrial sectors appear in the literature, but the creative industries - theatre, art galleries, book publishing and music publishing (Caves, 2000) - though financially important in most economies are under explored (Wong et al., 2005). The creative industries have been used for analysis in studies on: the Resource-Based View (RBV) of the firm using the major U.S. film studios (Miller and Shamsie, 1996); the relationship between technology acquisition and innovations in small media firms (Puranam et al., 2006); the role of innovation as strategic change, drawing on SMEs producing computer games (Hotho and Champion, 2011); consumer attitudes and service (Parry et al., 2012); and the role of the business model (Bustinza et al., 2013).

Creative content can be consumed in several forms. Music and motion picture content can be accessed via analogue streaming (TV, Radio), or paid for through 
licences for inclusion in films, video-games and for public broadcast (e.g. bars, shops, etc.). Following digitalization content can be accessed in forms including internet based streaming, downloads, social network placements etc. (Olson and Boyer, 2005). As a result creators and licensing firms are engaging customers through a diverse set of link channels. The dominant management orientation for link channels remains the traditional approach of managing content as a product. According to Ellram et al. (2006, pp. 17) SCM "is still strongly skewed toward the manufacturing sector" and managed using classical supply chain management techniques. The hypotheses stated are based on the assumption that customers are part of the value chain and that it is possible to engage them though link channels.

\subsection{Hypotheses}

As opportunities for achieving competitive advantage shift from internal to external integration (Frohlich and Westbrook, 2002) it becomes important to develop effective link channels to the customer (Bowersox and Closs, 1996). In the SCM literature link channels refer exclusively to dependences in a vertical supply chain (Häkansson and Snehota, 1995). Customer linking is a boundary spanning activity and this link to customers is essential in improving relationships (Wong et al., 2012). Customer responsiveness is enhanced through an early capture of demand information (Campbel and Sankaranl, 2005), highlighting the importance of analyzing customer attitudes and establishing mechanisms that link customer attitude to purchase (Parry et al., 2012). Through link channels, firms directly share their value offerings based upon their interpretation of demand. Customers continually push for new and improved value and the link channel is important as it is the final mechanism for display of value offerings. Properly managed, link channels reveal the match between the OPP (Order Penetration 
Point) of the supplier and VOP (Value Offering Point) of the customer (Hoover et al., 2001). Link channels are the customer engagement platform and are a mechanism to articulate the proposition of a value chain. From these antecedents the following hypotheses are stated such that:

H1: Consumer attitude to purchasing is mediated by link channels.

H1a: Consumer attitude to purchasing in product form is due to the mediation effects of link channels.

H1b: Consumer attitude to purchasing in service form is due to the mediation effects of link channels.

The hypotheses proposed and the model of relations between variables is shown in Figure 1.

\section{<INSERT FIGURE 1 ABOUT HERE>}

\section{Methodology}

\subsection{Industry sector selection}

This paper analyzes the effect of the introduction of services into traditional manufacturing firms. The music industry was a physical product based industry sector where firms had, and it could be argued many still have, a predominantly SCM approach. The sector has seen revenues fall following the introduction of digital services. The introduction of additional service offerings was driven by external innovations in the form of digital music provision and availability of broadband internet, mobile smart-phones and digital music devices, MP3 music encoding, online retail etc. Services often give higher margins than products, but digital service introduction in the music industry has decreased margins for artists and licence holders, 
particularly when compared to similar innovations in other creative industries (Daniels, 2006).

The music industry is led by 3 major music licensing firms who hold $60-70 \%$ by sales of market share to rights to physical and digital music resources (Informa Telecoms \& Media, 2010). The revenues they have received have been in sharp decline over the past decade (BPI, 2010). The firms operated focussed SCM product management during the period of strong revenue returns (Byrne, 2012). The decline in music industry revenues corresponds to the period in which the offering expanded from only product (e.g. CD, Vinyl and tape) to offering a range of products and services (e.g. iTunes, Spotify), with the digital offering coupled with a significant issue related to illegal sharing of content. This shift from product to product and service introduces a degree of asymmetric competition between new entrants (e.g. Apple or Spotify) and incumbent firms (major licensing firms). According to Desarbo et al. (2006) under asymmetric competition demand information constructed from consumer surveys is informative and complementary to supply-side information from firm data. For instance, when taking a supply chain perspective empirical research into product or service would assume the same outcome is provided to the consumer, and would likely provide no visibility of new entrants with small market share. However, a demand based perspective tests the different value consumers assign product and service formats, and through such analysis captures the potential market share gained by new entrants (Priem et al., 2012). Our empirical approach examines this value shift through analysis of an extensive consumer data set.

\subsection{Sample}


An empirical investigation was carried out to test the hypotheses stated. The study population selected is made up of resident music consumers in the UK. The statistical software SPSS 20 and EQS 6.2 are used to analyze the sample data. The questionnaire and responses are provided by one of the Big 3 'global music companies'. The questionnaire used has been undergoing iterative development for a number of years within the company. The questionnaire is extensive and only a subset of questions directly relating to the attributes, characteristics of consumer behaviour and link channels relevant to this study is selected. To analyse the data, in-depth semi-structured interviews of two hours duration were held with three senior managers, in order to avoid issues associated with single-informant data. The managers interviewed were the leaders of the three functional areas of the company. A qualitative approach was taken during interview analysis to provide understanding and clarification of the content of the questionnaire to be used. During interviews three researchers were present and made notes which were collated into detailed reports. The reports were discussed with the survey developer to ensure understanding and validity of constructs. The subset of questions selected from the full survey for use in this analysis was validated for coherence by the industry expert interviewees. In the UK a total of 4,227 valid questionnaire responses are obtained. Response rate varies by demographics but averaged $22 \%$, similar to other studies in the field of supply chain management (Cambra-Fierro and Polo-Redondo, 2008).

\subsection{Measures and Justification}

Music Consumers Attitudes: This scale measures the heterogeneity of consumers by their attitudes and is based on previous research which defines customer music consumption attitudes in the UK (Parry et al., 2012), recognising distinct consumer 
attitudinal groups labelled as Early adopter, Explorative, Cautious and Band Fan. These constructs are formed by a set of items included in the questionnaire using a 5point Likert scale $(1=$ Total disagreement, $5=$ Total agreement $)$. Through principal component analysis with varimax rotation and Kaiser normalization, respondents are categorized under one of the four consumer groups. Kaiser-Meyer-Olkin, Barlett's test of sphericity and Total variance are shown in Table I, indicating that factor analysis for each dimension is appropriate (Hair et al., 2001). The analysis of the scale's internal consistency gives a Cronbach's alpha value of $\alpha=0.928$, which is a weighted average of the correlations between items. All values indicate that these scales are valid measurement instruments (Cronbach, 1951). Nevertheless, high internal consistency may work against content validity so further tests are required. Mean Inter-item Correlation (MIC) is calculated, giving values $0.421,0.426,0.400$ and 0.416 . This shows the instruments are valid as none exceed the criterion 0.5 level, which is the level above which it is assumed the "items are overly redundant and the construct measured too specific" (Briggs and Cheek, 1986, p. 114). This criterion was followed to analyze all the scales. Cronbach's alpha assumes that all the items have the same relevance and tends to underestimate the true reliability when the data are multidimensional (Nunally, 1998). Additional indexes including Parallel (different measures have identical true scores and error variances), Tau-Equivalent (different measures have identical true scores but need not have equal error variances) and Congeneric Measures Reliability (different measures have only perfect correlation among their true scores) were performed following Raykov indications (1997a, 1997b). All values were over 0.700, which is required for validity (Hair et al., 2001) and are included in Table I.

Link Channels: As above, a scale composed of a 5-point Likert, from 1= Total disagreement, $5=$ Total agreement, is developed to group the main link channels used 
in the music industry (Table II). MIC showed a value of 0.398 . For analysis of the scale's internal consistency the Cronbach's alpha value is calculated, as well as parallel, tau-equivalent and congeneric reliabilities (Table I).

Purchasing Behaviours: Music purchasing scale is constructed following the same process as that utilised to construct music consumer attitudes, again a 5-point Likert scale $(1=$ Total disagreement; $5=$ Total agreement $)$ based on findings of Parry et al. (2012). MIC was 0.384 and the set of reliability indicators are reported in Table I.

<INSERT TABLE I ABOUT HERE>

$<$ INSERT TABLE II ABOUT HERE >

\section{Findings}

Table III (Link channels) shows factorial load and reliability analysis. Results from Structural Equations Modelling are shown in Table IV. A mediation relationship is established between the variables following the recommendations of Baron and Kenny (1986). The hypotheses are tested using this model to examine the extent to which link channels are determinants of consumer attitudes to product and service consumption (Table V)

\section{<INSERT TABLE III ABOUT HERE> \\ <INSERT TABLE IV ABOUT HERE>}

\subsection{The effect of link channels on consumer attitudes to purchase}

The discussion is structured with an exploration of each consumer type by attitude. Early Adopters (21.2\% of market): The results (Figure 2, Table V) show a total mediation role with regard to the Early Adopters attitudes to product and services supporting H1a $(\beta=0.070$, non-significance, n.s.; previous $\beta=0.298, p<0.001)$ and $\mathrm{H} 1 \mathrm{~b}$ $(\beta=0.019$, n.s.; previous $\beta=0.315, \mathrm{p}<0.001)$. Analysing the role of link channels in 
shaping the attitude of Early Adopters to purchasing product and service, there is partial mediation of H1 $(\beta=0.139$, n. s.; previous $\beta=0.382, p<0.001)$. This shows that the purchasing attitudes demonstrated by Early Adopters towards product and services as a whole can only be partially driven using link channels. Early adopters are fully mediated through link channels in the consumption of services and product independently. However, there is only partial mediation for consumption of both as the firm's offerings are perceived as substitutes. This will lead to cannibalization of the revenues from this group. To avoid the perception of substitutive offerings and limit revenue cannibalization it is proposed that products be managed under supply chain principles and services under a demand-supply chain approach when targeting this group. Services may be differentiated through the degree of customer integration (Moeller, 2008) determined by the visibility obtained of their needs (Collin et al., 2009) and focus placed upon delivery of offerings which are responsive in meeting their visible needs (Cambra-Fierro and Polo-Redondo, 2008).

Explorative Consumers (15.8\% of market): The results (Figure 2 and Table V) show link channels provide total mediation over the Explorative Consumers attitudes to product consumption, supporting H1a $(\beta=0.049$, non-significance; previous $\beta=0.558$, $\mathrm{p}<0.001)$. When the Explorative consumers attitude to service consumption is analyzed the results show that link channels have a negative effect on their attitude towards service consumption $(\beta=-0.158, \mathrm{p}<0.001)$ which rejects $\mathrm{H} 1 \mathrm{~b}$. Analysis shows that link channels make this group less likely to purchase, meaning that the traditional supply chain management approach employed is inappropriate. Traditional supply chain management approaches for products are often based upon transactional relationships with customers, characterized by the firm delivering to the customer and then reacting to their feedback (Khan et al., 2006). The results show that services need to be managed 
with a different management orientation, confirming the findings of Larsson and Bowen (1989).

Band Fans (20.4\% of market): For this group (Figure 2, Table V) the analysis of link channels and Band Fans attitudes to purchasing shows no effect, rejecting $H 1(\beta=0.289$, $\mathrm{p}<0.001$; previous $\beta=0.385, \mathrm{p}<0.001$ ). The analysis of the consumers with Band Fan attitudes towards product purchase shows the group is influenced by link channels, supporting hypotheses H1a $(\beta=0.081$, n.s.; previous $\beta=0.325, \mathrm{p}<0.001)$. With regards link channels and service, the H1b is rejected $(\beta=-0.081, p<0.001$; previous $\beta=0.317$, $\mathrm{p}<0.001)$. Results suggest that the value chain employed to sell service is inappropriate for this group. To engage customers in service purchases requires firms adopt an alternative management orientation. Some customers like to feel involved and engaged (Parry et al., 2012) which suggests a strong customer-driven facet is required in the management of the services offered to them (Grönroos, 1994). It is proposed that a demand-supply chain management approach for service offerings better recognises this group's needs (Jaworski and Kohli, 1996; Wong et al., 2012).

Cautious Consumers (42.7\% of market): The results (Figure 2, Table V) show that Cautious Consumer attitudes towards purchasing music are positive but not mediated by link channels, H1 $(\beta=0.193, p<0.001$; previous $\beta=0.251, p<0.001)$. Analyzing Cautious consumer attitudes to product or service separately, the results are the same H1a $(\beta=0.040, \mathrm{p}<0.001)$ and $\mathrm{H} 1 \mathrm{~b}(\beta=0.079, \mathrm{p}<0.001)$, meaning that these consumers have a positive attitude to purchasing that becomes neutral when both offers are available. The finding supports the perception of product and services as alternative substitutive offerings. In this context, the customers appear unwilling to pay for new offerings, which suggests they do not perceive that a diversity of offerings adds value (Atasu and Souza, 2012; Desai, 2001). The group perceives the prior product only offer is of 
comparatively greater value than the broader product and services offering. This supports the need to apply a different management orientation for service to address customer value perception and needs (Larsson and Bowen, 1989). Where product and service are offered the adoption of different strategies, for example SCM focussed for product and demand-supply chain for service, is required which reflects the shift in power towards the customer in service offerings (Soliman and Youssef, 2001).

\section{<INSERT FIGURE 2 ABOUT HERE>}

\section{$<$ INSERT TABLE V ABOUT HERE>}

To sum up, Hypotheses $\mathrm{H} 1$ and $\mathrm{H} 1 \mathrm{~b}$ are rejected for Explorative, Band Fan and Cautious Consumers (see Table VI for a summary), $80 \%$ of consumers according to Parry et al. (2012). To better understand the hypotheses rejected, Figure 3 is included. Following the model for designing customer aligned supply chains from Collin et al. (2009) and the visibility-based services supply chain design by Holmström et al. (2010), Figure 3 shows the representations of the traditional product value chain and the demand-supply service value chain. When products are the only offering available the link channels function using the traditional value chain. Visibility of the customer is only at the point of purchase and retailers are the order penetration point (OPP) (Holmström et al., 2010). A SCM strategic approach exists which ably supports a solely product led value chain (Byrne, 2012; Khan et al., 2006). In the service context much greater information about consumer preference is potentially available as the consumer interacts with the service, generating user specific data (Grönroos, 2011). The OPP is therefore complemented by a Requirements Penetration Point (RPP) which takes available consumer data to shape the service delivered (Holmström et al., 2010). For example, music services such as the 'Apple Genius' function of iTunes and \#musictwitter collect both use data and expressed preferences from registered users. This data 
may be employed to categorise the user, inform them of offerings which they may enjoy and thus reposition the providers resource and potentially reshape the offering. Table VI shows that the introduction of service offerings has effectively broken the traditional value chain and requires that competence of demand-supply chain management for the service offering is developed.

\section{<INSERT TABLE VI ABOUT HERE> \\ <INSERT FIGURE 3 ABOUT HERE>}

\section{Conclusions}

\subsection{Theoretical contribution}

This paper answers the research question: how does changing the offering affect supply \& demand chain management? Empirical analysis is based on consumer survey information to better assess the complexity of the asymmetric competitive arena when dealing with new business models (Desarbo et al., 2006; Priem et al., 2012). Evidence provided expands the SCM literature and demonstrates that the traditional manufacturing supply chain is effectively broken (Khan et al., 2006) when services are added to the firms product portfolio. It is proposed that service delivery benefits from a relationship based engagement, conceptualised by the Demand Chain Management literature (Cambra-Fierro and Polo-Redondo, 2008; Godseel et al., 2006; Lin et al., 2012; Singh and Power, 2009) as opposed to transactional engagements.

At a theoretical level, the supply chain has fundamentally changed due to the digitalization of the output (Graham and Smart, 2010). This paper has analyzed product firms that offer service offerings which may be product substitutes and establishes theoretical instruments to identify changes required in management orientation. If service offerings do not generate additional value as perceived by their customers the 
total value of the portfolio offerings can decrease (Desai, 2001). It is proposed that this may be addressed through integration of DCM and SCM strategies. Development of competence in integrated demand and supply chains may aid recovery of value in industries encountering this problem.

Chase et al. (2007) state that DCM is a dynamic network that enhances profitmaking relationships with customers and this paper sheds light on how this is achieved for services through customers linking channels. When the customer is integrated within the firm and empowered, as is the case with service, the research shows that the traditional supply value chain is effectively broken. A challenge for SCM is providing the customer with the right product, but also with the right service (Cambra-Fierro and Polo-Redondo, 2008; Hoover et al., 2001). Provision of service requires the presence and interaction of the customer (Prahalad and Ramaswamy, 2000). Providers need to identify consumer expectations (Parasuraman et al., 1985). This is a question which integrates the marketing function into the supply chain as integration of visible customer preferences and demand signals are incorporated into the service supply chain as primary construct, leading to greater customer insight and improved value offering (Hoover et al., 2001).

With regards the customers' role in value chain management, as shown in the results, firms need to consider link channels as a means to engage different consumer groups, categorised by their attitude. This supports previous findings which highlights the importance of considering customer differences when re-designing supply chains (Collin et al., 2009). Engagement with customers is effective when firms realize a demand-supply chain representation, model the dynamics of the visibility of customer demand, and consider OPP as applied to products and utilize the potential additional RPP for services (Holmström et al., 2010). The growing complexity of firms offering 
products and services is related to the specialised resources required; some of the specialised resource may now be provided by the customer in order to realise value (Lambert et al., 1999; Mills et al., 2012). In a landscape where product and services are embodied as part of the firm portfolio, firms need to question the management orientation of their value chain. This research proposes an appropriate management dyad encompassing SCM-DCM for services.

\subsection{Managerial implications}

This paper shows that customers' have different needs with regards product and service (Grönroos, 1994; Singh and Power, 2009), reinforcing the importance of understanding service management. Differentiation in the management orientation between products and services such that the customer can clearly identify the value of the offer available may re-engage a number of customers representing lost revenue (Desai, 2006). The customers identified have a positive attitude to purchase of the firms offer, but will only engage in purchasing if the link channels which are used to reach them are managed appropriately (Frohlich and Westbrook, 2002; Jelassi and Leenen, 2003).

Our findings suggest that there are two motivations for introducing specific value chain perspectives for product and service. From the data presented in this paper $21 \%$ of consumers (early adopters) perceive the offerings as substitutes while the remaining $79 \%$ of consumers were not engaged with service offerings. Several arguments can be found in the literature to support the existence of a positive link between customer integration and firm performance (Danese and Romano, 2011). If firms are able to link to customers through an appropriate management orientation the research presented here suggests that revenues will positively reflect this effort. It is proposed that, following categorization of customers by their attitude, trials and learning through DCM 
adoption focus on the most proactive group of consumers who are likely to actively engage with the firm, in this study those are the early adopters.

\subsection{Limitations and Future Research}

This data is a result of an online survey panel so it is presumed respondents are experienced with the digital environment and so the sample may have a bias. Although important relations between the variables included in this study were found the results must be interpreted with some caution as the study is exploratory and its goal is to examine interrelations between variables. Moreover, since this is a cross-sectional analysis it does not capture the dynamic nature of the factors that determine the relationship between the variables. This means that even if the relationships are significant other factors not included in the current study may also play an important role. This analysis deals exclusively with UK data and there is no data to test if the result is highly country-specific.

Future research will focus on the nature of the relations analyzed in other country contexts. A case study illustrating how changes in value offering affect the organization of supply/service provision will be required to add to the understanding of the findings. The addition of digital services will change the market structure of many industries and introduce numerous value propositions driven by consumer provided data. Future research will focus upon methods for identification of appropriate business models with which to create value offerings responsive to the greater visibility of consumer demand.

\section{References}

Agrawal, D.K. (2012), "Demand chain management: factors enhancing market responsiveness capabilities", Journal of Marketing Channels, Vol. 19 No. 2, pp. 101-19. 
Anderson, E.W., Fornell, C. and Rust, R.T. (1997), "Customer satisfaction, productivity, and profitability: differences between goods and services", Marketing Science, Vol. 16 No. 2, pp. 129-45.

Atasu, A. and Souza, G. (2011),"How does product recovery affect quality choice?", Production and Operations Management, forthcoming.

Barratt, M., Choi, T.Y. and Li, M. (2011), "Qualitative case studies in operations management: trends, research outcomes, and future research implications", Journal of Operations Management, Vol. 29, No 4, pp 329-42.

Baron, R.M. and Kenny, D.A. (1986), " The moderator-mediator variable distinction in social psychological research: conceptual, strategic, and statistical considerations", Journal of Personality and Social Psychology, Vol. 51 No. 6, pp. 1173-82.

Bettis, R.A. and Hitt, M.A. (2007), "The new competitive landscape", Strategic Management Journal, Vol. 16 No. 1, pp. 7-19.

Bowersox, D.J. and Closs, D.J. (1996), Logistical Management: The Integrated Supply Chain Process, McGraw-Hill Companies, New York, NY.

Briggs, S.R. and Cheek, J.M. (1986), "The role of factor analysis in the development and evaluation of personality scales", Journal of Personality, Vol. 54 No. 1, pp. 106-48.

British Phonographic Industry-BPI (2010), Statistical Handbook, BPI, London.

Bustinza, O.F., Parry G., Vendrell-Herrero, F. and Myrthianos, V. (2013), "Music business models and piracy", Industrial Management \& Data Systems, Vol. 113 No 1, pp. 4-22.

Byrne, D. (2012), How Music Works, Canongate Books, Edinburgh.

Cambra-Fierro, J.J. and Polo-Redondo, Y. (2008), "Creating satisfaction in the demand-supply chain: the buyers' perspective", Supply Chain Management: An International Journal, Vol. 13 No. 3, pp. 211-24.

Canever, M.D., Van Trijp, H.C.M. and Beers, G. (2008), "The emergent demand chain management: key features and illustration from the beef business", Supply Chain Management: An International Journal, Vol. 13 No. 2, pp. 104-15.

Caves, R. (2000), Creative Industries: Contracts between Art and Commerce, Harvard University Press, Cambridge, MA.

Campbell, J. and Sankaranl, J. (2005), "An inductive framework for enhancing supply chain integration", International Journal of Production Research, Vol. 43 No. 16, pp. 321-51.

Chase, R.B., Jacobs, F.R., Aquilano, N.J. and Agrawal, N.K. (2007), Operations Management for Competitive Advantage, Tata McGraw-Hill, New Delhi.

Christopher, M. (2005), Logistics and Supply Chain Management: Creating Value-Adding Networks, Pearson education, NY. 
Collin, J., Eloranta, E. and Holmström, J. (2009), "How to design the right supply chains for your customers", Supply Chain Management: An International Journal, Vol. 14 No. 6, pp. 411-17.

Cronbach, L.J. (1951), "Coefficient alpha and the internal structure of tests", Psychometrika, Vol. 16 No. 3, pp. 297-334.

Danese, P. and Romano, P. (2011), "Supply chain integration and efficiency performance: a study on the interactions between customer and supplier integration", Supply Chain Management: An International Journal, Nol. 16 No. 4, pp. 220-30.

Daniels, M. (2006). "Brave New World: the opportunities for booksellers and the booksellers association", The bookseller association from England and Ireland report, available at: http://www.booksellers.org.uk/News-Industry-Info/Industry-Reports.aspx (accessed 15 June 2012).

Desai, P.S. (2001), "Quality segmentation in spatial markets: when does cannibalization affect product line design?", Marketing Science, Vol. 20 No. 3, pp. 265-84.

Desarbo, W.S., Grewal, R. and Wind, J. (2006), "Who competes with whom? A demand-based perspective for identifying and representing asymmetric competition", Strategic Management Journal, Vol. 27 No. 2, pp.101-129.

Dyer, J.H. and Nobeoka, K. (2000), "Creating and managing a high-performance knowledgesharing network: the Toyota case", Strategic Management Journal, Vol. 21 No. 3, pp. 34567.

Edwards, J., McKinnon, A. and Cullinane, S. (2011), "Comparative carbon auditing of conventional and online retail supply chains: a review of methodological issues", Supply Chain Management: An International Journal, Vol. 16 No. 1, pp. 57-63

Ellinger, A., Shin, H., Northington, W.M., Adams, F.G., Hofman, D., and O'Marah, K. (2012), "The influence of supply chain management competency on customer satisfaction and shareholder value", Supply Chain Management: An International Journal, Vol. 17 No. 3, pp. 249-62.

Ellram, L.M. and Cooper, M.C. (1990), "Supply chain management, partnership, and the shipper-third party relationship", International Journal of Logistics Management, Vol. 1 No. 2, pp. 1-10.

Ellram, L.M., Tate, W.L. and Carter, C.R. (2007), "Product-process-supply chain: an integrative approach to three-dimensional concurrent engineering", International Journal of Physical Distribution \& Logistics Management, Vol. 37 No. 4, pp. 305-30.

Ellram, L.M., Tate, W.L. and Billington, C. (2006), "Understanding and managing the services supply chain", Journal of Supply Chain Management, Vol. 40 No. 4, pp. 17-32.

Forrester, J. (1961), Industrial Dynamics, MIT Press, Massachusetts.

Frohlich, M.T. and Westbrook, R. (2002), "Demand chain management in manufacturing and services: web-based integration, drivers and performance", Journal of Operations Management, Vol. 20 No. 6, pp. 729-45. 
Giannakis, M. (2011), "Management of service supply chains with a service-oriented reference model: the case of management consulting", Supply Chain Management: An International Journal, Vol. 16 No. 5, pp. 346-61.

Godsell, J., Harrison, A., Emberson, C. and Storey, J. (2006), "Customer responsive supply chain strategy: an unnatural act?", International Journal of Logistics: Research and Applications, Vol. 9 No. 1, pp. 47-56.

Graham, G. and Smart, A. (2010),"The regional-newspaper industry supply chain and the internet", Supply Chain Management: An International Journal, Vol. 15 No. 3, pp. 196206.

Green, K.W., McGaughey, R. and Casey, K.M. (2006), "Does supply chain management strategy mediate the association between market orientation and organizational performance?", Supply Chain Management: An International Journal, Vol. 11 No. 5, pp. 407-14.

Goffin, K. (1999), "Customer support: a cross-industry study of distribution channels and strategies", International Journal of Physical Distribution \& Logistics Management, Vol. 29 No. 6, pp. 374-97.

Grönroos, C. (1994), "From scientific management to service management: a management perspective for the age of service competition", International Journal of Service Industry Management, Vol. 5 No. 1, pp. 5-20.

Grönroos, C. (2011), "A service perspective on business relationships: the value creation, interaction and marketing interface", Industrial Marketing Management, Vol. 40 No. 2, pp. 240-7.

Hair, J.F., Anderson, R.E., Tatham, R.L. and Black, W. (2001), Multivariate Data Analysis, Prentice-Hall Pearson Education: London.

Hakansson, H. and Snehota, I. (1995), Developing Relationships in Business Networks, Routledge, London.

Heskett, J.L., Sasser, W.E. and Schlesinger, L.A. (1997), The Service Profit Chain: How Leading Companies Link Profit and Growth to Loyalty, Satisfaction, and Value, Simon and Schuster, NY.

Holmström, J., Brax, S., and Ala-Risku, T. (2010), "Comparing provider-customer constellations of visibility-based service", Journal of Service Management, Vol. 21 No. 5, pp. 675-92.

Holmström, J., Hoover, W., Vasara, A. and Louhiluoto, P. (2000), "The other end of the supply chain", McKinsey Quarterly, No 1, pp. 1-8.

Hoover, W.E., Eloranta, E., Holmström, J. and Huttunen, K. (2001), Managing the DemandSupply Chain: Value Innovations for Customer Satisfaction, Wiley\&Sons, New York, NY.

Hotho,S. and Champion, K. (2011), "Small businesses in the new creative industries: innovation as a people management challenge", Management Decision, Vol. 49 No. 1, pp. 29-54. 
Horvath, L. (2001), "Collaboration: the key to value creation in supply chain management", Supply Chain Management: An International Journal, Vol. 6 No. 5, pp. 205-17.

Informa Telecoms \& Media (2010), "Universal Music Group reasserts its recorded-music dominance in 2010", available at:

"http://musicandcopyright.wordpress.com/2011/03/23/universal-music-group-reasserts-itsrecorded-music-dominance-in-2010/" (accessed 23 May 2012).

Jaworski, B.J. and Kohli, A.K. (1996), "Market orientation: review, refinement, and roadmap", Journal of Market-Focused Management, Vol. 1 No. 2, pp. 119-35.

Jelassi, T. and Leenen, S. (2003), "An E-commerce sales model for manufacturing companies: a conceptual framework and a European example", European Management Journal, Vol. 21 No. 1, pp. 38-47.

Johnsen, T., Howard, M., and Miemczyk, J. (2009),"UK defence change and the impact on supply relationships", Supply Chain Management: An International Journal, Vol. 14 No.4, pp. $270-9$

Johnson, G., Scholes, K. and Whittington, R. (2008), Exploring Corporate Strategy: Text \& Cases, Prentice Hall, NY.

Johnston, R. (1999), "Service operations management: return to roots", International Journal of Operations and Production Management, Vol. 19 No. 2, pp. 104-24.

Jüttner, U., Christopher, M. and Baker, S. (2007), "Demand chain management-integrating marketing and supply chain management", Industrial Marketing Management, Vol. 36 No. 3, pp. 377-92.

Kahn, K.B., Maltz, E.N., and Mentzer, J.E. (2006) "Demand collaboration: effects on knowledge creation, relationships and supply chain performance", Journal of Business Logistics, Vol.27 No.2, pp.191-221.

Larsson, R. and Bowen, D.E. (1989), "Organization and customer: managing design and coordination of services", The Academy of Management Review, Vol. 14 No. 2, pp. 213-33.

Lee, C.W., Kwon, I.W.G. and Severance, D. (2007), "Relationship between supply chain performance and degree of linkage among supplier, internal integration, and customer", Supply Chain Management: An International Journal, Vol. 12 No. 6, pp. 444-52.

Lee, H.L., Padmanabhan, V. and Whang, S. (1997), "The bullwhip effect in supply chains", Sloan Management Review, Vol. 38 No. 3, pp. 93-102.

Lin, R.J., Che, R.H. and Ting, C.Y. (2012), "Turning knowledge management into innovation in the high-tech industry", Industrial Management \& Data Systems, Vol. 112 No. 1, pp. 4263 .

Maull, M., Geraldi, J. and Johnston, R. (2012), "Service supply chain: a customer perspective", Journal of Supply Chain Management, Vol. 48 No. 4, pp. 72-86.

McNaughton, R.B., Osborne, P. and Imrie, B.C. (2002), "Market-oriented value creation in service firms", European Journal of Marketing, Vol. 36 No. 9/10, pp. 990-1002. 
Mentzer, J.T., DeWitt, W., Keebler, J.S., Min S., Nix, N.W., Smith, C.D. and Zacharia, Z.G. (2011), "Defining supply chain management", Journal of Business Logistics, Vol. 22 No. 2 , pp. 1-25.

Metters, R. (1997), "Quantifying the bullwhip effect in supply chains", Journal of Operations Management, Vol. 15 No. 2, pp. 89-100.

Miller, D. and Shamsie, J. (1996), "The Resource-Based View of the firm in two environments: the Hollywood film studios from 1936 to 1965", The Academy of Management Journal, Vol. 39 No. 3, pp. 519-543.

Moeller, S. (2008), "Customer integration - a key to an implementation perspective of service provision", Journal of Service Research, Vol. 11 No. 2, pp. 197-210.

Ng, I., Parry, G., Wilde, P., McFarlane, D. and Tasker, P. (2011), Complex Engineering Service Systems: Concepts and Research, Springer: London.

Nunnally, J. (1978). Psychometric Theory, Mc-Graw Hill: New York, N.Y.

Oberholzer-Gee, F. and Strumpf, K. (2007), "The effect of file sharing on record sales: an empirical analysis", Journal of Political Economy, Vol. 115 No. 1, pp. 1-42.

Oliva, R. and Kallenberg, R. (2003), "Managing the transition from products to services", Journal of Service Management, Vol. 14 No. 2, pp. 160-72.

Olson, J.R. and Boyer, K.K. (2005), "Internet ticketing in a not-for-profit, service organization: building customer loyalty", International Journal of Operations \& Production Management, Vol. 25 No. 1, pp. 74-92.

Parasuraman, A., Zeithaml, V.A. and Berry, L.L. (1985), "A conceptual model of service quality and its implications for future research", Journal of Marketing, Vol. 49 No. 4, pp. $41-50$.

Parry, G., Bustinza, O.F. and Vendrell-Herrero, F. (2012), "Servitisation and value coproduction in the UK music industry: an empirical study of consumer attitudes", International Journal of Production Economics, Vol. 135 No. 1, pp. 320-32.

Parry, G., Mills, J. and Turner, C. (2010), "Lean Competence: integration of theories in operations management practice", Supply Chain Management: An International Journal, Vol. 15, No. 3, pp. 216-26

Prahalad, C.K. and Ramaswamy, V. (2000). Co-opting customer competence. Harvard Business Review, Vol. 78 No. 1, pp. 79-87.

Priem, R.L. and Swink, M. (2012). A demand-side perspective on supply chain management. Journal of Supply Chain Management, Vol. 48 No. 2, pp. 7-13.

Puranam, P., Singh, H. and Zollo, M. (2006), "Organizing for innovation: managing the coordination-autonomy dilemma in technology acquisitions", The Academy of Management Journal, Vol. 49 No. 2, pp. 263-80.

Raykov, T. (1997a), "Estimation of composite reliability for congeneric measures", Applied Psychological Measurement, Vol. 21 No. 2, pp. 173-84. 
Raykov, T. (1997b), "Scale reliability, Cronbach's coefficient alpha, and violations of essential tauequivalence with fixed congeneric components", Multivariate Behavioral Research, Vol. 32, No. 4, 329-53.

Sampson, S.E. (2010), "The unified service theory", in Salvendy, G. and Karwowski, W. (Ed.), Introduction to Service Engineering, John Wiley \& Sons, Hoboken, New Jersey, N.Y., pp. 34-56.

Singh, P.J. and Power, D. (2009), "The nature and effectiveness of collaboration between firms, their customers and suppliers: a supply chain perspective", Supply Chain Management: An International Journal, Vol. 14 No. 3, pp. 189-200.

Smâros, J., Holmström, J. and Kämäräinen, V. (2000), "New service opportunities in the egrocery business", International Journal of Logistics Management, Vol. 11 No. 1, pp. 6174.

Soliman, F. and Youssef, M. (2001), "The impact of some recent developments in e-business on the management of next generation manufacturing", International Journal of Operations \& Production Management, Vol. 21 No. 5/6, pp. 538-64.

Stock, J.R., Boyer, S.L. and Harmon, T. (2010), "Research opportunities in supply chain management", Journal of the Academy of Marketing Science, Vol. 38 No. 1, pp. 32-41.

Tolbert, P.S. and Zucker, L.G. (1983), "Institutional sources of change in the formal structure of organizations: the diffusion of civil service reform, 1880-1935", Administrative Science Quarterly, Vol. 28 No. 1, pp. 22-39.

Vandermerwe, S. and Rada, J. (1988), "Servitization of business: adding value by adding services", European Management Journal, Vol. 6 No. 4, pp. 314-24.

Vargo, S. and Lusch, R.F., (2008). "Service-dominant logic: continuing the evolution". Journal of the Academy of Marketing Science, Vol. 36 No.1, pp. 1-10.

Vollmann, T.E., Cordon, C. and Heikkila, J. (2000), "Teaching supply chain management to business executives", Production and Operations Management, Vol. 9 No. 1, pp. 81-90.

Wilkinson, A., Dainty, A. and Neely, A. (2009), "Changing times and changing timescales: the servitization of manufacturing", International Journal of Operations \& Production Management, Vol. 29 No. 5, pp. 425-30.

Wise, R. and Baumgartner, P. (1999), "Go downstream: the new profit imperative in manufacturing", Harvard Business Review, Vol. 77 No. 5, pp. 133-41.

Wong, C.Y. and Johansen, J. (2005), "Supply chain management practices in toy supply chains", Supply Chain Management: An International Journal, Vol. 10 No. 5, pp. 367-78.

Wong, C., Skipworth, H., Godsell, J. and Achimugu, N. (2012), "Towards a theory of supply chain alignment enablers: a systematic literature review", Supply Chain Management: An International Journal, Vol. 17 No. 4, pp. 419-37. 
Figure 1 Model of relationships

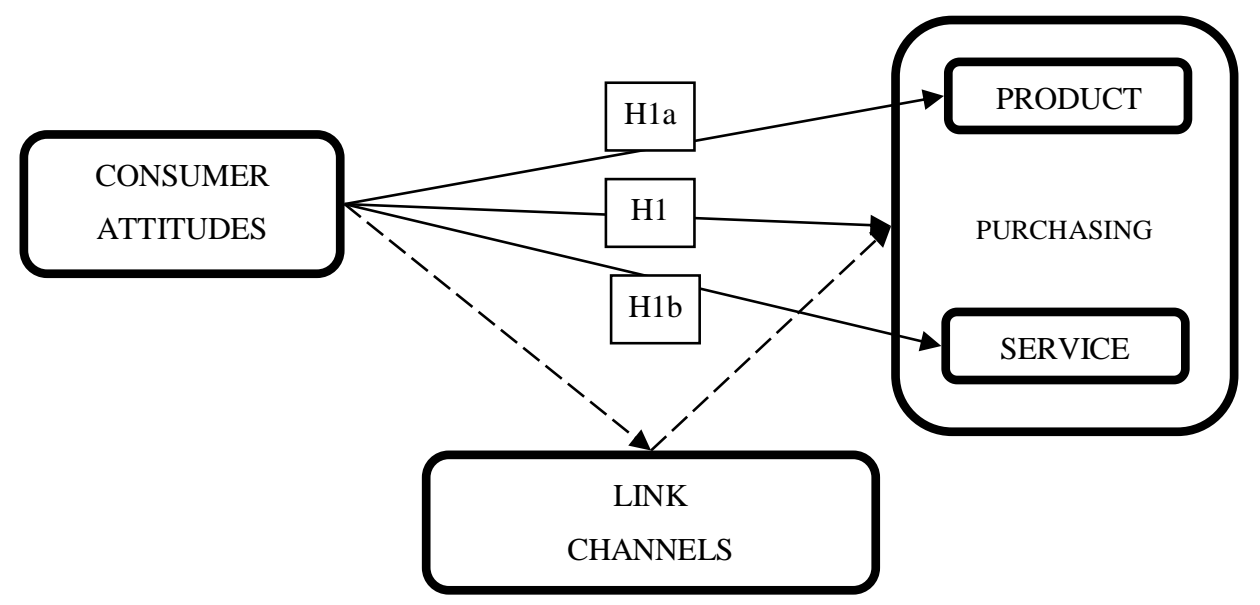

Figure 2 Structural equation model

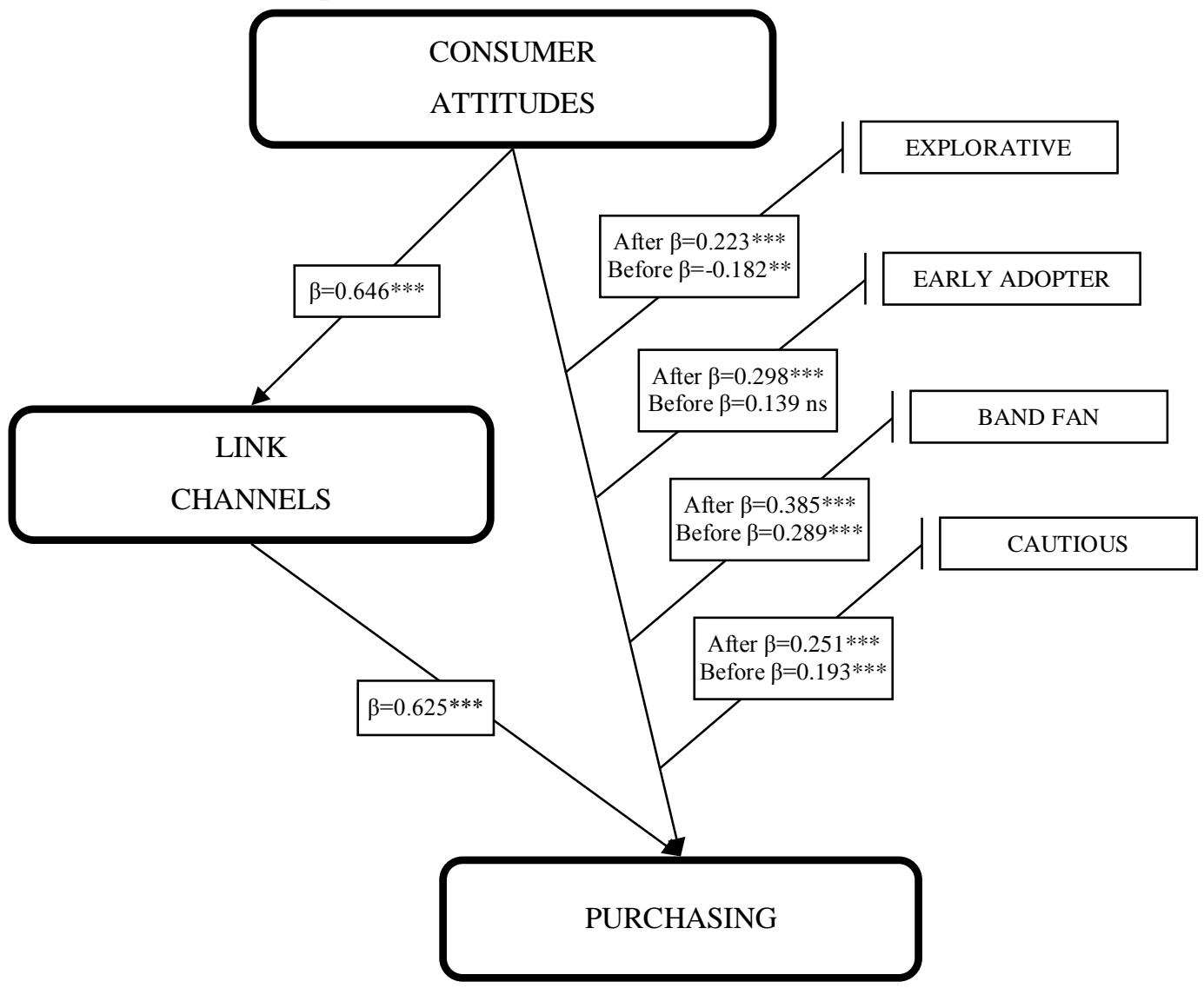


Figure 3 Representations of the value and demand-supply chain after adding services as alternative to products

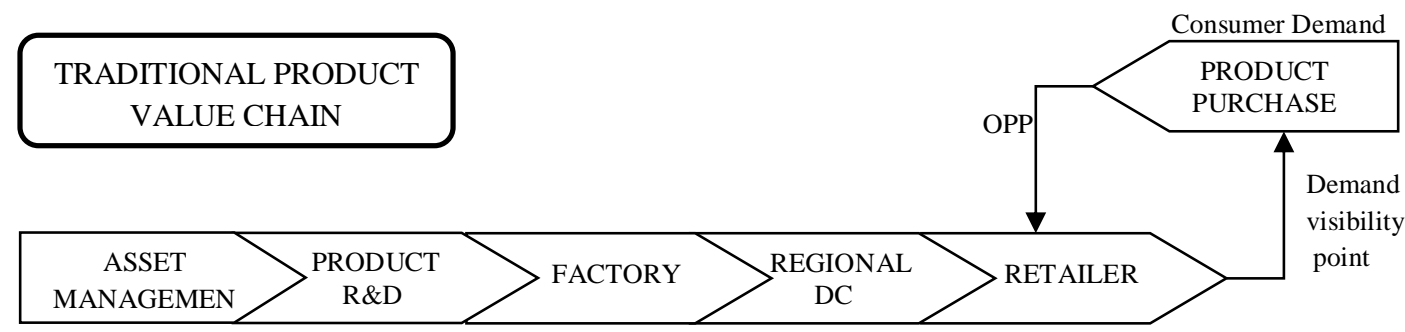

VISIBILITY-TO-PURCHASING

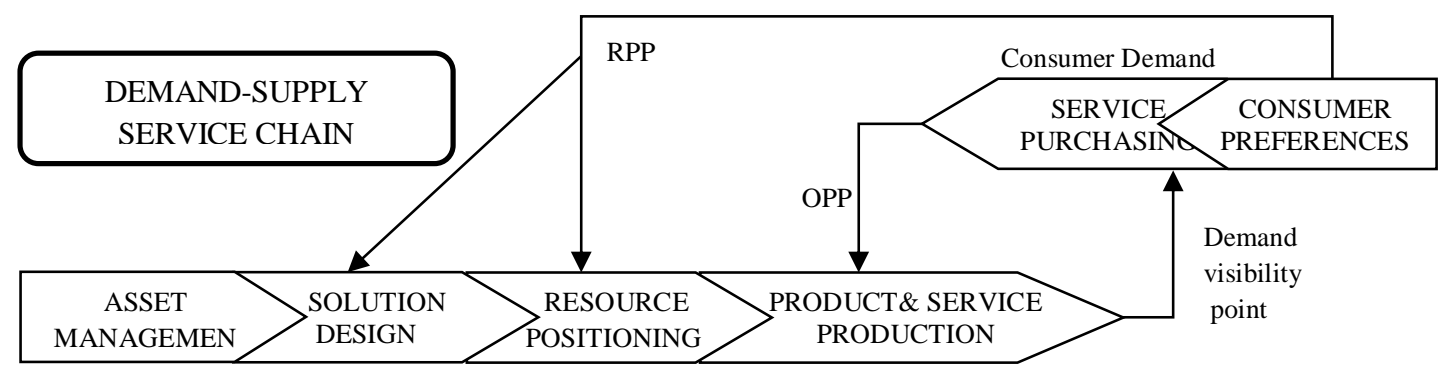

VISIBILITY-TO-PREFERENCES 
Table I Reliability of measure scales

\begin{tabular}{|c|c|c|c|c|}
\hline & Cronbach's Alpha & Parallel & Tau-equivalent & Congeneric \\
\hline $\begin{array}{c}\text { Early Adopters } \\
\text { T.V.E }=67.074 \% \\
\text { KMO }=0.900 \\
\chi 2=18,776.038(p=0.000) \\
\end{array}$ & 0.901 & 0.849 & 0.862 & 0.862 \\
\hline $\begin{array}{c}\text { Explorative } \\
\text { T.V.E }=55.517 \% \\
\text { KMO }=0.901 \\
\chi^{2}=13,737.255(\mathrm{p}=0.000)\end{array}$ & 0.865 & 0.820 & 0.838 & 0.834 \\
\hline $\begin{array}{c}\text { Cautious } \\
\text { T.V.E }=66.486 \% \\
\text { KMO }=0.814 \\
\chi{ }^{2}=11,490.944(p=0.000)\end{array}$ & 0.836 & 0.794 & 0.801 & 0.798 \\
\hline $\begin{array}{c}\text { Band Fans } \\
\text { T.V.E }=65.823 \% \\
\text { KMO }=0.868 \\
\chi 2=9,645.584(\mathrm{p}=0.000)\end{array}$ & 0.827 & 0.781 & 0.785 & 0.782 \\
\hline $\begin{array}{c}\text { Link Channels } \\
\text { T.V.E }=53.146 \% \\
\text { KMO }=0.813 \\
\chi 2=9,915.903(p=0.000)\end{array}$ & 0.906 & 0.855 & 0.857 & 0.859 \\
\hline $\begin{array}{c}\text { Product Purchasing } \\
\text { T.V.E }=72.010 \% \\
\text { KMO }=0.790 \\
\chi 2 \_8,176.234(p=0.000)\end{array}$ & 0.905 & 0.857 & 0.860 & 0.858 \\
\hline $\begin{array}{c}\text { Service Purchasing } \\
\text { T.V.E }=63.565 \% \\
\text { KMO }=0.912 \\
\chi 2=26,752.779(\mathrm{p}=0.000)\end{array}$ & 0.912 & 0.856 & 0.862 & 0.859 \\
\hline Legend: Total Variance E & ined (T.V.E.): Cum & $\%$ must & recommended & 0.5 \\
\hline
\end{tabular}

Table II Items measuring link channels

Please indicate to which extend ( $1=$ Total disagreement, $5=$ Total agreement) you consider these channels your usual way to decide what music to buy.

LINK1.- Analogue radio (non-digital).

LINK2.- Digital radio DAB.

LINK3.- Watching music TV channels.

LINK4.- Music watched live: At concerts, etc.

LINK5.- Music in bars and clubs.

LINK6.- Music used in film, TV, video games etc.

LINK7.- Music played straight from the internet (Internet radio/live streaming).

LINK8.- Music videos streamed online (e.g. from YouTube).

LINK9.- Social networking sites, such as Facebook, MySpace, etc.

LINK10.- Piracy. 
Table III Factor loadings and reliability analysis

\begin{tabular}{l|l|l|l|l|l}
\hline \multicolumn{5}{c}{ LINK CHANNELS } \\
\hline $\begin{array}{l}\text { Construct } \\
\text { items }\end{array}$ & Mean (S.D.) & $\begin{array}{l}\text { Factor Loading } \\
\text { (t-values) }\end{array}$ & $\mathrm{R}^{2}$ & $\begin{array}{l}\text { Composite } \\
\text { Reliability }\end{array}$ & $\begin{array}{l}\text { Variance } \\
\text { extracted }\end{array}$ \\
\hline LINK1 & $2.261(1.175)$ & $0.689(48.349)$ & 0.475 & 0.833 & 0.511 \\
LINK2 & $2.797(1.245)$ & $0.702(47.558)$ & 0.493 & & \\
LINK3 & $2.637(1.095)$ & $0.698(46.369)$ & 0.487 & & \\
LINK4 & $2.795(0.971)$ & $0.713(47.146)$ & 0.508 & & \\
LINK5 & $2.793(1.008)$ & $0.724(48.003)$ & 0.524 & & \\
LINK6 & $2.819(1.140)$ & $0.729(47.358)$ & 0.531 & & \\
LINK7 & $2.925(1.099)$ & $0.793(22.359)$ & 0.623 & & \\
LINK8 & $3.012(1.113)$ & $0.834(23.114)$ & 0.696 & & \\
\hline
\end{tabular}

All of the factor loadings are significant for a level of $\mathrm{p}<0.01$ 
Table IV Indicators of the goodness of fit for the UK market

\begin{tabular}{|c|c|c|c|c|c|c|c|}
\hline TYPE OF FIT & INDICATOR & NOMEN & $\begin{array}{c}\text { ACCEPTANCE } \\
\text { RANGE }\end{array}$ & EXPLO & EARLY & CAUTIOUS & BAND FAN \\
\hline \multirow{4}{*}{ ABSOLUTE } & $\begin{array}{l}\text { Chi-Square } \\
\text { Likelihood }\end{array}$ & CMIN & $\begin{array}{l}\text { Significance } \\
\text { test }\end{array}$ & $\begin{array}{l}3333.927 \\
(\mathrm{p}<0.01)\end{array}$ & $\begin{array}{l}2831.709 \\
(p<0.01)\end{array}$ & $\begin{array}{l}3650.091 \\
(p<0.01)\end{array}$ & $\begin{array}{l}3783.653 \\
(p<0.01)\end{array}$ \\
\hline & $\begin{array}{l}\text { Goodness-of- } \\
\text { Fit Index }\end{array}$ & GFI & $>0.900$ & 0.951 & 0.946 & 0.945 & 0.953 \\
\hline & $\begin{array}{l}\text { Root Mean } \\
\text { Square Error }\end{array}$ & RMSEA & $0.050-0.080$ & 0.064 & 0.058 & 0.062 & 0.060 \\
\hline & $\begin{array}{c}\text { Root Mean } \\
\text { Residual }\end{array}$ & RMR & $<0.050$ & 0.034 & 0.033 & 0.043 & 0.039 \\
\hline \multirow{4}{*}{ INCREMEN } & $\begin{array}{l}\text { Compared Fit } \\
\text { Index }\end{array}$ & CFI & $>0.900$ & 0.952 & 0.949 & 0.953 & 0.963 \\
\hline & $\begin{array}{l}\text { Normed Fit } \\
\text { Index }\end{array}$ & NFI & $>0.900$ & 0.951 & 0.948 & 0.947 & 0.960 \\
\hline & $\begin{array}{l}\text { Tucker-Lewis } \\
\text { Index }\end{array}$ & NNFI & $>0.900$ & 0.937 & 0.936 & 0.936 & 0.951 \\
\hline & $\begin{array}{c}\text { Adjusted } \\
\text { Goodness Fit }\end{array}$ & AGFI & $>0.900$ & 0.926 & 0.931 & 0.915 & 0.934 \\
\hline PARSIMONY & $\begin{array}{l}\text { Normed Chi- } \\
\text { square }\end{array}$ & CMINDF & Range (1-5) & 1.465 & 1.856 & 2.005 & 1.939 \\
\hline
\end{tabular}

Table V Acceptance/rejection of hypotheses for the UK market

Key: No effect - no mediation effect; Total mediation - attitude determined by mediator; Inverse attitude inverted by mediator; Partial mediation - attitude partially determined by mediator

\begin{tabular}{|c|c|c|c|c|}
\hline & $\begin{array}{c}\text { Explorative } \\
\text { Consumer }\end{array}$ & $\begin{array}{c}\text { Early } \\
\text { Adopter }\end{array}$ & $\begin{array}{l}\text { Band } \\
\text { Fan }\end{array}$ & $\begin{array}{l}\text { Cautious } \\
\text { Consumer }\end{array}$ \\
\hline $\begin{array}{c}\% \text { of market with this } \\
\text { attitude (Parry et al., 2012) }\end{array}$ & $15.77 \%$ & $21.22 \%$ & $20.41 \%$ & $42.60 \%$ \\
\hline $\begin{array}{l}\text { All channels and } \\
\text { Purchasing }\end{array}$ & $\begin{array}{c}\text { Inverse } \\
\text { H1.1: }-0.182^{* *} \\
\text { Prev. } \beta=0.223^{* * *}\end{array}$ & $\begin{array}{c}\text { Partial mediation } \\
\text { H2.1: } 0.139 n s \\
\text { Prev. } \beta=0.298^{* * *}\end{array}$ & $\begin{array}{c}\text { No effect } \\
\text { H3.1: } 0.289 * * * \\
\text { Prev. } \beta=0.385^{* * *}\end{array}$ & $\begin{array}{c}\text { No effect } \\
\text { H4.1: } 0.193 * * * \\
\text { Prev. } \beta=0.251^{* * *}\end{array}$ \\
\hline $\begin{array}{l}\text { All channels and Product } \\
\text { Consumption }\end{array}$ & $\begin{array}{l}\text { Total Mediation } \\
\text { H1.1a: 0.049ns } \\
\text { Prev. } \beta=0.558^{* * *}\end{array}$ & $\begin{array}{c}\text { Total Mediation } \\
\text { H2.1a: 0.070ns } \\
\text { Prev. } \beta=0.298^{* * *}\end{array}$ & $\begin{array}{c}\text { Total Mediation } \\
\text { H3.1a: 0.081ns } \\
\text { Prev. } \beta=0.325 * * *\end{array}$ & $\begin{array}{c}\text { No effect } \\
\text { H4.1a: } 0.040^{* * *} \\
\text { Prev. } \beta=0.011^{* * *}\end{array}$ \\
\hline $\begin{array}{c}\text { All channels and Service } \\
\text { Consumption }\end{array}$ & $\begin{array}{c}\text { Inverse } \\
\text { H1.1b: }-0.158^{* *} \\
\text { Prev. } \beta=0.525^{* * *}\end{array}$ & $\begin{array}{c}\text { Total Mediation } \\
\text { H2.1b: 0.019ns } \\
\text { Prev. } \beta=0.315^{* * *}\end{array}$ & $\begin{array}{c}\text { Inverse } \\
\text { H3.1b: }-0.081 * * * \\
\text { Prev. } \beta=0.317 * * *\end{array}$ & $\begin{array}{c}\text { No effect } \\
\text { H4.1b: } 0.079 * * \\
\text { Prev. } \beta=0.028 * * *\end{array}$ \\
\hline
\end{tabular}


*** Significant at the 0.001 level; ** Significant at the 0.01 level

Table VI Hypotheses rejected showing broken value chain

\begin{tabular}{c|c|c}
\hline $\begin{array}{c}\text { CONSUMER } \\
\text { ATTITUDES }\end{array}$ & PURCHASING & $\begin{array}{c}\text { HYPOTHESES } \\
\text { REJECTION }\end{array}$ \\
\hline \multirow{2}{*}{ EXPLORATIVE } & PRODUCT+SERVICE & H1: Rejected \\
\cline { 2 - 3 } & SERVICE & H1b: Rejected \\
\hline \multirow{2}{*}{ BAND FAN } & PRODUCT+SERVICE & H1: Rejected \\
\cline { 2 - 3 } & SERVICE & H1b: Rejected \\
\hline \multirow{2}{*}{$\begin{array}{c}\text { CAUTIOUS } \\
\text { CONSUMER }\end{array}$} & PRODUCT+SERVICE & H1: Rejected \\
\cline { 2 - 3 } & PRODUCT & H1a: Rejected \\
\cline { 2 - 3 } & SERVICE & H1b: Rejected \\
\hline
\end{tabular}

